\title{
PENGARUH PENDAPATAN, HARGA EMAS DAN TINGKAT INFLASI TERHADAP PENYALURAN KREDIT DI PEGADAIAN CABANG PADANG
}

\author{
MASRI BOY EKA PUTRA ${ }^{1}$, MUHAMMAD RIVANDI ${ }^{2}$ \\ SEKOLAH TINGGI ILMU EKONOMI KBP \\ ${ }^{1}$ Email : masriboyekaputra@yahoo.com \\ ${ }^{2}$ Muhamamdrivandi@akbpstie.ac.id
}

\begin{abstract}
ABSTRAK
Penyaluran kredit merupakan semua jenis pinjaman yang harus dibayar kembali bersama bunganya oleh peminjam sesuai dengan perjanjian yang telah disepakati. Penelitian ini bertujuan untuk mengetahui pengaruh pendapatan, harga emas dan tingkat inflasi terhadap penyaluran kredit . Jenis Penelitian yang digunakan kuantitatif. Objek penelitian pada PT. Pegadaian Cabang Padang pada tahun 2005 sampai 2016. Metode analisis menggunakan statistik non parametrik dengan menggunakan uji spearman's test correlation. Hasil uji spearman's test pendapatan dan harga emas mempunyai hubungan positif dengan penyaluran kredit sedangkan tingkat inflasi tidak mempunyai hubungan engan penyaluran kredit.
\end{abstract}

Kata kunci : Pendapatan, harga emas, tingkat inflasi dan penyaluran kredit.

ABSTRACK

The kredit distribution is all kind of loan which must be repaid by the borrower icluding bank interest in accordance agreement that been binding. The purpose of this research is to find out the influence of income, gold price and inflation rate on credit distribution. This research design is quantitativ research. The object of this research is PT. Pegadaian the branch of padang in 2005 until 2016. In analyzing the data, this research using stating statistical non parametrik method that uses spearman's test correlation. The result of the using spearman's test, both income and gold price have a correlation which is positive relationship with credit distribution. Mean while, the inflation rate has no correlation with credit distribution.

Key words: income, gold price, inflation rate and credit distribution 
Istilah kredit berasal dari bahasa Yunani, “credere”, yang artinya kepercayaan atau truth. Dasar kredit yang ditetapkan adalah kepercayaan seseorang atau badan yang memberikan kredit bahwa penerima kredit pada masa yang akan datang sanggup untuk memenuhi segala sesuatu yang telah dijanjikan, yaitu dapat berupa barang atau uang atau jasa. Dalam hal usaha, untuk meningkatkan usahanya dan meningkatkan daya guna suatu barang, seseorang mungkin membutuhkan bantuan dalam bentuk permodalan. Bantuan dari Bank maupun Lembaga Keuangan bukan Bank dalam bentuk tambahan modal inilah yang sering disebut dengan kredit.

Kegiatan perkreditan dapat terjadi dalam segala aspek kehidupan manusia. Semakin majunya perekonomian di masyarakat, maka kegiatan perkreditan semakin mendesak kegiatan perekonomian yang dilaksanakan secara tunai. Kegiatan perkreditan ini meliputi segala aspek ekonomi, baik di bidang produksi, distribusi, konsumsi, perdagangan, investasi maupun bidang jasa dalam bentuk uang tunai, barang dan jasa (Desriani and Rahayu, 2013).

Penyaluran kredit adalah semua jenis pinjaman yang harus dibayar kembali bersama bunganya ouleh peminjam sesuai dengan perjanjian yang telah disepakati. Kredit adalah suatu usaha pemberian prestasi baik berupa barang, jasa, atau uang dari suatu pihak (pemberi kredit) kepada pihak lain (penerima kredit) atas dasar kepercayaan dimana penerima kredit harus mengembalikan kredit yang diberikan pada waktu tertentu yang akan datang disertai dengan suatu kontra prestasi (balas jasa) berupa bunga sesuai dengan perjanjian yang telah disepakati (Kasmir, 2013).

Fungsi Kredit Menurut Kasmir (2013) fungsi kredit a) Untuk meningkatkan daya guna uang. Dengan adanya kredit dapat meningkatkan daya guna uang maksudnya jika uang hanya disimpan saja tidak akan menghasilkan sesuatu yang berguna. Dengan diberiakan kredit uang tersebut menjadi berguna untuk menghasilkan barang atau jasa oleh si penerima kredit. b) Untuk meningkatkan peredaran dan lalu lintas uang. Dalam hal ini uang yang diberikan atau disalurkan akan beredar dari satu wilayah ke wilayah lainnya sehingga suatu daerah yang kekurangan uang yang memperoleh kredit maka daerah tersebut akan memperoleh tambahan uang dari daerah lainnya.c) Untuk meningkatkan daya guna uang. Kredit yang diberikan oleh bank akan dapat digunakan oleh sidebitur untuk mengolah barang yang tidak berguna menjadi bermanfaat. d.)Meningkatkan peredaran barang. Kredit dapat pula menambah atau mempelancar arus barang dari satu wilayah ke wilayah lainnya sehingga jumlah barang yang beredar dari wilayah satu ke wilayah lainya bertambah atau kredit dapat pula meningkatkan barang yang beredar. e) Sebagai alat stabilitas ekonomi. Dengan memberikan kredit dapat dikatakan sebagai stabilitas ekonomi karna dengan adanya kredit yang diberikan akan menambah jumlah barang yang di perlukan oleh masyarakat. f. ) Untuk meningkatkan kegairahan beusaha. Bagi sipenerima kredit tentu akan meningkatkan kegairahan berusaha apalagi bagi nasabah yang modal nya pas-pasan. g.) Untuk meningkatkan pemerataan pendapatan. Semangkin banyak kredit yang disalurkan akan semakin baik terutama dalam hal meningkatkan pendapatan. Jika sebuah kredit dapat membangun, maka pabrik tersebut akan membutuhkan tenaga kerja dan dapat mengurangi angka pengangguran.

Faktor yang mempengaruhi Penyaluran kredit adalah Pendapatan, harga emas dan tingkat inflasi. Pendapatan disebut juga dengan income yaitu imbalan yang diterima oleh seluruh rumah tangga pada lapisan masyarakat dalam suatu negara atau daerah, dari penyerahan faktor-faktor produksi atau setelah melakukan kegiatan perekonomian. Pendapatan tersebut digunakan oleh masyarakat untuk memenuhi kebutuhan konsumsi dan sisanya merupakan tabungan untuk memenuhi hari depan (Desriani and Rahayu, 2013). 
Pendapatan disebut juga dengan income yaitu imbalan yang diterima oleh seluruh rumah tangga pada lapisan masyarakat dalam suatu negara/daerah, dari penyerahan faktor-faktor produksi atau setelah melakukan kegiatan perekonomian. Pendapatan tersebut digunakan oleh masyarakat untuk memenuhi kebutuhan konsumsi dan sisanya merupakan tabungan untuk memenuhi hari depan Febrian (2013). Pengelolaan kinerja dalam memberikan peningkatan laba, yang memberikan gambaran kondisi keuangan perusahaan (Rivandi, Saleh and Septiano, 2017) dan (Rivandi, 2017)

Pegadaian selain melayani kepentingan umum juga bertujuan untuk mendapatkan laba. Pegadaian terus berupaya meningkatkan fasilitas yang diberikan guna untuk meningkatkan pendapatan, semakin banyak pendapatan yang diperoleh maka menggambarkan semangkin banyak pula kredit yang dapat disalurkan kepada nasabahnya Hal ini mengindikasikan bahwa variabel pendapatan berbanding lurus dengan kredit yang disalurakan terhadap masyarakat. Semakin besar pendapatan yang diperoleh, semakin besar pula dana atau kredit yang dapat diberikan kepada masyarakat luas (Desriani and Rahayu, 2013).

Menurut Purnomo (2008) Mengemukakan bahwa pendapatan juga berpengaruh positif terhadap penyaluran kredit. Pendapatan pada perum pegadaian yang mencerminkan semakin maraknya kegiatan penyaluran kredit melalui bidang bidang usaha perum pegadaian yang secara berkelanjutan mencerminkan pergerakan usaha perekonomian bagi masyarakat. Penelitian ini juga sejalan dengan penelitian Desriani and Rahayu (2013), Widiarti \& Sinarti (2013) dan Rosa et al (2017).

Semakin banyak pendapatan yang diperoleh maka menggambarkan semangkin banyak pula kredit yang dapat disalurkan kepada nasabahnya. Semakin besar pendapatan yang diperoleh, semakin besar pula dana atau kredit yang dapat diberikan kepada masyarakat luas. Berdasarkan teori dan penelitian terdahulu dapat diturunkan hipotesis yang akan dibuktikan secara empiris :

\section{$\mathrm{H}_{1}$ : Pendapatan berpengaruh Positif terhadap Penyaluran Kredit.}

Tingkat harga emas mempengaruhi jumlah kredit yang disalurkan karena barang yang paling sering digadaikan adalah emas. Oleh karena itu tingkat harga emas sangat mempengaruhi jumlah taksiran barang lainnya. Naik atau turunnya harga emas dapat berdampak pada penyaluran kredit dipegadaian. Harga emas yang terus mengalami kenaikan berdampak pada peningkatan omset pegadaian. Semangkin tinggi harga emas maka semangkin tinggi pula penyaluran kredit dipegadaian begitu pula sebaliknya (Febrian, 2013).

Desriani and Rahayu (2013) menyatakan harga emas berpengaruh positif dan signifikan terhadap penyaluran kredit atau omzet Pegadaian di seluruh Indonesia. Nilai harga emas memiliki kecenderungan selalu meningkat dari tahun ke tahun. Dengan dominasi emas yang sangat tinggi terhadap industri gadai dan penyesuaian nilai taksiran yang diberlakukan telah disesuaikan dengan kenaikan harga emas, menjadikan masyarakat lebih memilih alternatif gadai, dibandingkan dengan jika harus menjual perhiasan yang dimilik.

Penelitian yang dilakukan Rahmawati (2016) harga emas berpengaruh positif terhadap penyaluran kredit di pegadaian, harga emas yang terus mengalami kenaikan berdampak pada peningkatan omset pegadaian. Semangkin tinggi harga emas maka semangkin tinggi pula penyaluran kredit dipegadaian begitu pula sebaliknya. Berdasarkan teori dan penelitian terdahulu dapat diturunkan hipotesis yang akan dibuktikan secara empiris :

\section{$\mathrm{H}_{2}$ : Harga Emas berpengaruh positif terhadap Penyaluran Kredit}


Aziz (2013) Tingkat inflasi merupakan proses kenaikan harga-harga umum barang secara terus menerus. Ini tidak berarti bahwa harga-harga berbagai macam barang itu naik dengan persentase yang sama. Mungkin dapat terjadi kenaikan tersebut tidaklah bersamaan. Inflasi yang penting terdapat kenaikan harga umum barang secara terus menerus selama satu periode tertentu.

Pengaruh inflasi ini melalui tingkat bunga nominal, dikarenakan tingkat bunga riil yang terbentuk dari tingkat bunga nominal dikurangi inflasi. Apabila tingkat inflasi tinggi maka tingkat bunga riil akan menurun, ini akan mengakibatkan naiknya jumlah penyaluran kredit yang diakibatkan turunnya tingkat bunga riil.

Penelitian yang dilakukan Rosa, Husni, and Idwar (2017) Hasil pengujian menunjukkan bahwa tingkat inflasi berpengaruh negatif terhadap penyaluran kredit rahn. Berarti setiap kenaikan tingkat inflasi akan menurunkan penyaluran kredit karena tingkat inflasi merupakan faktor ekonomi yang bersifat eksternal dari perusahaan dimana semakin tinggi tingkat inflasi maka jumlah kredit yang disalurkan akan menurun.

Berdasarkan Sari \& Abundanti (2016) Menunjukkan bahwa tingkat inflasi juga tidak berpengaruh terhadap penyaluran kredit. meningkatnya inflasi kecil pengaruhnya terhadap penyaluran kredit. Hal ini disebabkan karena tingkat fluktuasi pada inflasi yang terjadi dari periode 2011- 2015 terjadi fluktuasi yang rendah. Inflasi yang berfluktuasi rendah terjadi karena inflasi masih dapat dikendalikan oleh pemerintah, sehingga menyebabkan kecil pengaruhnya terhadap suku bunga bank yang akan mempengaruhi penyaluran kredit pada bank umum. Penelitian ini juga sejalan dengan penelitian yang dilakukan oleh (Dewi, 2016), (Febrian, 2013), (Widiarti \& Sinarti, 2013).

Dengan menggunakan asumsi suku bunga riil jika terjadi inflasi naik maka expected profit akan mengalami kenaikan dan permintaan kredit turut juga mengalami kenaikan, tetapi jika inflasi naik yang diakibatkan dengan kenaikan nominal interest rate, sehingga permintaan kredit juga akan naik. Berdasarkan teori dan penelitian terdahulu dapat diturunkan hipotesis yang akan dibuktikan secara empiris :

\section{$\mathrm{H}_{3}$ : Tingkat Inflasi berpengaruh negatif terhadap Penyaluran Kredit}

\section{METODE PENELITIAN}

Pada penelitian ini penulis memilih jenis penelitian kuantitatif. Menurut penelitian kuantitatif merupakan metode ilmiah/scientific karena telah memenuhi kaidah-kaidah ilmiah yaitu konkrit/empiris, objektif, terukur, rasional dan sistematik. Dan juga disebut metode kuantitatif karena data pada penelitian berupa angka-angka dan analisis menggunakan statistik Sugiyono (2015). Pada penelitian ini bertujuan untuk meneliti pengaruh pendapatan, harga emas dan tingkat inflasi terhadap penyaluran kredit di PT.Pegadaian Cabang Padang.

Jenis data didalam penelitian ini adalah time series. Pengukuran yang digunakan dalam time series adalah time rasio. Dimana data rasio merupakan data tentang keterang yang memberikan nilai yang diukurdari nilai absolut.Sumber penelitian ini mengambil laporan keuangan pada PT. Pegadaian Cabang Padang.

Teknik pengumpulan data yang dipakai dalam penelitian ini adalah metode dokumentasi 
pengumpulan data dengan pengamatan, dimana peneliti tidak terlibat langsung dalam aktivitas tapi hanya sebagai pengamat independen. Peneliti mengumpulkan Laporan Keuangan PT Pegadaian Cabang Padang dari tahun 2005 sampai 2016. Data yang diperlukan dilaporan keuangan yaitu pendapatan, harga emas, tingkat inflasi dan penyaluran kredit. Data yang dikumpulkan sebanyak 12 data.

\section{Defenisi Operasional Variabel}

Penyaluran kredit adalah semua jenis pinjaman yang harus dibayar kembali bersama bunganya oleh peminjam sesuai dengan perjanjian yang telah disepkati (kasmir, 2013) pengukuran penyaluran kredit Pendapatan adalah arus masuk bruto dari manfaat ekonomi yang Timbul dari aktivitas normal perusahaan selama suatu periode bila arus masuk itu mengakibatkan kenaikan ekuitas yang tidak berasal dari kontribusi penanaman modal (Febrian, 2013). Pengukuran untuk Pendapatan adalah Jumlah pendapatan bersih.

Harga Emas adalah sejumlah uang yang dikorbankan atau dibayarkan untuk memperoleh komoditi atau produk berupa emas (Desriani and Rahayu, 2013). Pengukuran Harga Emas adalah jumlah harga emas.

Tingkat Inflasi adalah kemerosotan nilai uang (kertas) karena banyaknya dan cepatnya uang (kertas) beredar sehingga menyebabkan naiknya harga barang-barang (Widiarti and Sinarti, 2013) pengukuran Tingkat Inflasi adalah laju inflasi.

\section{Teknik Analisis Data}

Teknik analisis data yang dipakai dalam penelitian ini adalah non parametrik. Statistik non parametrik yaitu satistik bebas sebaran (tidak mensyaratkan bentuk sebaran parameter populasi, baik normal atau tidak) (Sugiyono, 2011). Selain itu, statistik non parametrik biasanya menggunakan skala pengukuran social, yakni nominal dan ordinal yang umumnya tidak berdistribusi normal.Statistik yang non parametrik yang dipakai adalah : analisis spearman test correlation. Spearman's Rho Korelasi digunakan untuk mengetahui korelasi dua variabel ditinjau dari peringkatnya, maksudnya yang dikorelasikan adalah peringkatnya, jadi sebelum melakukan korelasi menggunakan spearman, maka terlebih dahulu peneliti memeringkatkan data yang diperolah dari peringkat 1 hingga peringkat $\mathrm{n}$ berdasarkan data yang diperoleh (Djuniadi, Afiffudin and Lestari, 2016a). Hasil pengujian spearman dapat dikatakan berhubungan korelasi apabila nilai signifikansi (2-tailed) $<0,05$ sedangkan apabila nilai signifikansi (2-tailed) $>0,05$ maka tidak memiliki hubungan correlation

\section{HASIL DAN PEMBAHASAN}

\section{Statistik Deskriptif}

Tabel 4.1

Statistic Deskriptif

\section{Descriptive Statistics}




\begin{tabular}{|l|l|l|l|l|l|}
\hline & $\mathrm{N}$ & Minimum & Maximum & Mean & $\begin{array}{l}\text { Std. } \\
\text { Deviation }\end{array}$ \\
\hline Pendapatan & 12 & $\begin{array}{l}1410868953 \\
513\end{array}$ & 9708058303878 & 514531333 & $\begin{array}{l}314853278 \\
2684.33\end{array}$ \\
harga emas & 12 & 139081.00 & 520927.00 & 362489.66 & 136178.26 \\
& 12 & 2.78 & 17.11 & 67 & 003 \\
tingkat inflasi \\
$\begin{array}{l}\text { penyaluran } \\
\text { kredit }\end{array}$
\end{tabular}

Berdasarkan tabel 4.1 diatas bahwa variabel penelitian yang digunakan dalam penelitian ini adalah penyaluran kredit dengan menggunakan istilah $\mathrm{Y}$, pendapatan dengan istilah $\mathrm{X} 1$, harga emas dengan istilah $\mathrm{X} 2$, tingkat inflasi dengan istilah X3. Total data yang digunakan berjumlah 12 tahun.

Secara keseluruhan penyaluran kredit terendah di PT.Pegadaian Cabang Padang adalah 308709000000.00, penyaluran kredit tertinggi adalah 14096937999999.00, tingkat rata-rata penyaluran kredit di PT. Pegdaian cabang padang sebesar 6669001833333.2500 dengan standar deviasi 5416215108324.65800. Selanjutnya pendapatan (X1) terendah di PT.Pegadaian cabang padang sebesar 1410868953513, tingkat pendapatan (X1) tertinggi adalah sebesar 9708058303878, tingkat rata-rata pendapatan PT.Pegadaian cabang padang sebesar 5145313332684.33 dengan standar deviasi 3148532782500.682.

Harga emas (X2) terendah yang penah terdapat d PT. Pegadaian cabang padang sebesar 139081.00, tingkat harga emas (X2) tertinggi di PT. Pegadaian cabang padang sebesar 520927.00, dan secara keseluruhan pada umum nya di PT. Pegadaian Cabang Padang tingkat rata-rata harga emas adalah sebesar 362489.6667 dengan standar deviasi 136178.26003.

Selanjutnya tingkat inflasi (X3) terendah yang pernah diiliki oleh PT.Pegadaian cabang padang sebesar 2.78, sedangkan tingkat inflasi (X3) tertinggi yang pernah dimiliki sebesar 17.11, dan secara keseluruhan yang pernah dimiliki di PT. Pegadaian cabang padang tingkat rata-rata tingkat inflasi nya sebesar 6.8558 dengan standar deviasi 4.12444.

\section{Uji Spearman test}

Spearman's Rho korelasi digunakan untuk mengetahui korelasi variael ditimjau dari peringkat nya, maksud yang dikorelasikan adalah peringkat nya, jadi sebelum melakukan korelasi menggunakan spearman maka terlebih dahulu peneliti memeringkat kan data yang diproleh dari peringkat 1 hingga peringat dan berdasarkan data yang yang di peroleh (Djuniadi, Afiffudin, and Lestari, 2016). Hasil pengujian spearman dapat dikatakan berhubungan korelasi apabila nilai signifikansi (2-tailed) $<0,05$ sedangkan apabila nilai signifikansi (2-tailed) $>0,05$ maka tidak memiliki hubungan korelasi. 
Tabel 4.2

Pengukuran Spearman Test

\begin{tabular}{|c|c|c|c|c|c|c|}
\hline \multicolumn{7}{|c|}{ Correlations } \\
\hline & & & Pendapatan & harga emas & $\begin{array}{l}\text { tingkat } \\
\text { inflasi }\end{array}$ & $\begin{array}{l}\text { penyaluran } \\
\text { kredit }\end{array}$ \\
\hline \multirow[t]{4}{*}{$\begin{array}{l}\text { Spear } \\
\text { man's } \\
\text { rho }\end{array}$} & Pendapatan & $\begin{array}{l}\text { Correlation } \\
\text { Coefficient } \\
\text { Sig. (2-tailed) } \\
\text { N } \\
\end{array}$ & $\begin{array}{l}1.000 \\
\cdot \\
12\end{array}$ & $\begin{array}{l}.881^{* *} \\
.000 \\
12 \\
\end{array}$ & $\begin{array}{l}-.434 \\
.159 \\
12 \\
\end{array}$ & $\begin{array}{l}.993^{* *} \\
.000 \\
12 \\
\end{array}$ \\
\hline & harga emas & $\begin{array}{l}\text { Correlation } \\
\text { Coefficient } \\
\text { Sig. (2-tailed) } \\
\mathrm{N} \\
\end{array}$ & $\begin{array}{l}.881^{* *} \\
.000 \\
12 \\
\end{array}$ & $\begin{array}{l}1.000 \\
. \\
12 \\
\end{array}$ & $\begin{array}{l}-.455 \\
.138 \\
12 \\
\end{array}$ & $\begin{array}{l}.909^{* *} \\
.000 \\
12 \\
\end{array}$ \\
\hline & tingkat inflasi & $\begin{array}{l}\text { Correlation } \\
\text { Coefficient } \\
\text { Sig. (2-tailed) } \\
\text { N } \\
\end{array}$ & $\begin{array}{l}-.434 \\
.159 \\
12 \\
\end{array}$ & $\begin{array}{l}-.455 \\
.138 \\
12 \\
\end{array}$ & $\begin{array}{l}1.000 \\
. \\
12 \\
\end{array}$ & $\begin{array}{l}-.427 \\
.167 \\
12 \\
\end{array}$ \\
\hline & $\begin{array}{l}\text { penyaluran } \\
\text { kredit }\end{array}$ & $\begin{array}{l}\text { Correlation } \\
\text { Coefficient } \\
\text { Sig. (2-tailed) } \\
\text { N }\end{array}$ & $\begin{array}{l}.993^{* *} \\
.000 \\
12\end{array}$ & $\begin{array}{l}.909^{* *} \\
.000 \\
12\end{array}$ & $\begin{array}{l}-.427 \\
.167 \\
12\end{array}$ & $\begin{array}{l}1.000 \\
\cdot \\
12\end{array}$ \\
\hline
\end{tabular}

**. Correlation is significant at the 0.01 level (2-tailed).

Berdasarkan tabel 4.2 dilihat model korelasi spearman's test untuk variabel pendapatan dengan penyaluran kredit diperoleh model correlation yang dihasilkan bernilai 0,993 dengan nilai sig $=0,00<5 \%$. Hasil yang didapatkan menunjukan bahwa pendapatan mempunyai hubungan positif yang signifikan terhadap penyaluran kredit. Kesimpulan hasil menunjukkan bahwa pendapatan berhubungan positif dengan penyaluran kredit di PT Pegadaian Cabang Padang

Pada tabel 4.2 model correlation spearman test untuk variabel harga emas terhadap penyaluran kredit. Diperoleh model correlation yang dihasilkan bernilai 0,909 dengan nilai sig $=0,00<5 \%$. Hasil yang didapatkan menunjukan bahwa harga emas mempunyai hubungan positif yang signifikan terhadap penyaluran kredit. Kesimpulan hasil menunjukkan bahwa harga emas berhubungan positif dengan penyaluran kredit di PT Pegadaian Cabang Padang 
Pada tabel 4.2 model correlation spearman test untuk variabel tingkat inflasi korelasi terhadap penyaluran kredit. Diperoleh model correlation yang dihasilkan bernilai 0,-427 dengan nilai sig $=0,167 \geq 5 \%$. Hasil yang didapatkan menunjukan bahwa tingkat inflasi tidak ada hubungan yang signifikan terhadap penyaluran kredit. Kesimpulan hasil menunjukkan bahwa inflasi tidak berhubungan dengan penyaluran kredit di PT Pegadaian Cabang Padang.

\section{Pembahasan \\ Hubungan Pendapatan dengan Penyaluran Kredit}

Berdasarkan tabel 4.2. menunjukkan hasil uji spearman's test correlation pendapatan berhubungan positif dengan penyaluran kredit di PT Pegadaian Cabang Padang. Pendapatan disebut juga dengan income yaitu imbalan yang diterima oleh seluruh rumah tangga pada lapisan masyarakat dalam suatu negara/daerah, dari penyerahan faktor-faktor produksi atau setelah melakukan kegiatan perekonomian. Pendapatan tersebut digunakan oleh masyarakat untuk memenuhi kebutuhan konsumsi dan sisanya merupakan tabungan untuk memenuhi hari depan (Febrian, 2013).

Hasil yang diperoleh dapat interpretasikan bahwa pendapatan berhubungan positif dengan penyaluran kredit. Pendapatan telah ditetapkan oleh pihak PT. Pegadaian Cabang Padang sangat mempengaruhi penyaluran kredit. Semakin tingginya tingkat pendapatan maka semakin banyak pula kredit yang disalurkan kepada nasabah. Terlihat pada tahun 2005 total pendapatan sebesar Rp. 1.410.868.953.513 kredit yang disalurkan pada tahun 2005 sebanyak Rp. 308.709.000.000 sedangkan di tahun 2006 total pendapatan sebesar Rp. 1.939.785.864.050 kredit yang disalurkan pada tahun 2006 sebesar Rp. 591.087.000.000. artinya semakin tinggi pendapatan maka akan semakin banyak pula kredit yang disalurkan. Pendapatan dari nasabah di pegadaian Cabang Padang menambah income pada perusahaan sehingga perusahaan dapat memberikan kredit kenasabah lebih banyak.

\section{Hubungan Harga Emas dengan Penyaluran Kredit}

Berdasarkan tabel 4.2 menunjukkan hasil uji spearman's test correlation harga emas berhubungan positif dengan penyaluran kredit di PT Pegadaian Cabang Padang. Harga emas menurut Desriani and Rahayu (2013) adalah harga spot yang terbentuk dari akumulasi penawaran dan permintaan di pasar emas London. Harga emas yang digunakan adalah hasil lelang kelima anggota London Gold Fixing. Data harga emas dunia yang digunakan adalah harga penutupan (close price-Gold P.M) akhir bulan.

Harga emas berhubungan positif dengan penyaluran kredit di PT. Pegadaian Cabang Padang karena harga emas yang cenderung meningkat dari tahun ke tahun menjadikan masyarakat lebih memilih alternatif gadai di bandingkan dengan menjual perhiasan emas yang dimiliki. Terlihat pada tahun 2011 harga emas sebesar Rp. 457.143 kredit yang disalurkan sebesar Rp. 7.822.599.000.000 sedangkan pada tahun 2012 harga emas sebesar Rp. 520.927 kredit yang disalurkan sebesar Rp. 11.122.404.999.999 artinya semakin naik nya harga emas dari tahun ke tahun maka akan semakin meningkat nya nasabah menggunakan jasa gadai.

\section{Hubungan Tingkat Inflasi dengan Penyaluran Kredit}


Berdasarkan tabel 4.2 bahwa uji spearman's test correlation Inflasi tidak berhubungan terhadap penyaluran kredit di PT Pegadaian Cabang Padang. Walaupun terjadinya penurunan atau naik nya tingkat inflasi tidak ada hubungan nasabah untuk memilih jasa gadai karna Inflasi yang berfluktuasi rendah terjadi karena inflasi masih dapat dikendalikan oleh pemerintah, sehingga menyebabkan kecil pengaruhnya terhadap suku bunga bank yang akan mempengaruhi penyaluran kredit pada pegadaian.

Aziz (2013) Tingkat inflasi merupakan proses kenaikan harga-harga umum barang secara terus menerus. Ini tidak berarti bahwa harga-harga berbagai macam barang itu naik dengan persentase yang sama. Mungkin dapat terjadi kenaikan tersebut tidaklah bersamaan. Inflasi yang penting terdapat kenaikan harga umum barang secara terus menerus selama satu periode tertentu.

Tingkat inflasi tidak ada hubungan dengan penyaluran kredit di PT. Pegadaian Cabang Padang dikarenakan masyarakat ingin hidup diluar batas kemampuan ekonominya. Inflasi merupakan gejala ekonomi makro yang memiliki daya beli masyarakat akan menurun karena naik nya harga-harga pokok kebutuhan hal tersebut yang membuat masyarakat kurang untuk menggunakan jasa gadai di PT. Pegadaian Cabang Padang.

\section{KESIMPULAN DAN SARAN}

\section{Kesimpulan}

a. Pendapatan berhubungan positif dengan penyaluran kredit di PT Pegadaian Cabang Padang

b. Harga emas dengan penyaluran kredit adalah berhubungan posiif di PT Pegadaian Cabang Padang

c. Tingkat inflasi tidak berhubungan positif dengan penyaluran kredit di PT Pegadaian Cabang Padang

\section{Saran}

a. Bagi Perusahaan

Berdasarkan hasil yang diperoleh dalam penelitian ini, bahwa jumlah kredit yang disalurkan oleh PT Pegadaian cabang Padang dipengaruhi oleh indikator-indikator eksternal maupun internal seperti Inflasi, Pendapatan Pegadaian dan Harga Emas maka diperlukan langkah-langkah untuk lebih meningkatkan perhatiannya terhadap ketiga komponen tersebut, dengan harapan semakin stabilnya kondisi Pegadaian dan meningkatkan kembali peran Pegadaian untuk mengatasi masalah masyarakat dalam upaya menyelaraskan pembangunan dan pertumbuhan ekonomi di Indonesia.

b. Bagi Penelitian Selanjutnya

1. Mengingat variabel bebas yang baik merupakan hal yang sangat penting dalam mempengaruhi penyaluran kredit gadai diharapkan hasil penelitian ini dapat dipakai sebagai acuan bagi peneliti selanjutnya untuk mengembangkan penelitian ini dengan mempertimbangkan variabel - variabel lain diluar variabel bebas dalam penelitian ini.

2. Diharapkan pada penelitian selanjutnya, dilakukan pada Lembaga Non Perbankan lainnya dan menggunakan variabel yang berbeda sehingga diharapkan dapat memberikan gambaran secara umum mengenai pengaruh penyaluran kreditt

\section{UCAPAN TERIMA KASIH}

Terima kasih peneliti sampaikan kepada: 
1. Bapak Febryandhie Ananda, SE, M.Si selaku ketua STIE"KBP" Padang yang telah memberikan fasilitas dan kemudahan kepada penulis sehingga studinya dapat berjalan dengan lancer.

2. Ibu Lidya Martha, SE, MM selaku wakil ketua STIE"KBP” Padang.

3. Ibu Afriyeni, SE, MM selaku direktur AKBP Padang.

4. Ibu Dewi Zulfia, SE,MM selaku ketua Program Studi Akuntansi Sekolah Tinggi Ilmu Ekonomi "Keuangan Perbankan Pembangunan" Padang.

5. Bapak Muhammad Rivandi, S.E, M.Si selaku Dosen Pembimbing penulis, yang telah membimbing penulis dengan penuh kesabaran dari awal proposal sampai saat sekarang ini

6. Ibu Lisa Amelia Herman, S.E, M.Si selaku Dosen Pembimbing Akademik.

7. PT. Pegadaian Cabang Padang yang telah berkenan membantu dengan memberikan data laporan keuangan dalam penelitian ini.

8. Semua pihak yang telah memberikan dukungan beserta bantuannya dalam menyelesaikan skripsi ini.

\section{DAFTAR PUSTAKA}

Aziz, M. A. (2013) 'Analisis Pengaruh Tingkat Sewa Modal, Jumlah Nasabah, Harga Emas Dan Tingkat Inflasi Terhadap Penyaluran Kredit Gadai Golonang c (Studi Pada PT Pegadaian Cabang Probolinggo)', Jurnal Ilmiah.

Desriani, I. P. and Rahayu, S. (2013) 'Analisis Pengaruh Pendapatan, Harga Emas Dan Tingkat Inflasi Terhadap Penyaluran Kredit (Studi Kasus Pada Perum Pegadaian Cabang Jombang, Tangerang Periode Maret 2009 - September 2011)', Jurnal Akuntansi dan Keuangan, 2(2), pp. $147-165$.

Dewi, A. S. (2016) 'Pengaruh Jumlah Nasabah, Tingkat Suku Bunga Dan Inflasi Terhadap Penyaluran Kredit Pada PT Pegadaian Di Cabang Samarinda Seberang Kota Samarinda', Jurnal Ekonomi dan Keuangan, 13(2), pp. 71-81.

Djuniadi, Afiffudin, M. and Lestari, W. (2016a) Statistik Inferensial. Teori, Aplikasi dan Latihan Soal dengan SPSS. Semarang: Program Pascasarjana Universitas Negeri Semarang.

Djuniadi, Afiffudin, M. and Lestari, W. (2016b) Statistik Inferensial.Teori, Aplikasi dan Latihan Soal Dengan SPSS. Semarang: Program Pasca Sarjana Universitas Negeri Semarang.

Febrian, D. (2013) 'Analisis pengaruh tingkat inflasi, pendapatan pegadaian dan harga emas terhadap penyaluran kredit rahn pada pt pegadaian syariah di indonesia (periode 2005-2013)', Skripsi Fakultas Ekonomi dan Bisnis Universitas Islam Negeri Syarif Hidayatullah.

kasmir (2013) Bank Dan Lembaga Keuangan Lainnya. PT.RAJAGRAFINDO PERSADA.

Purnomo, A. (2008) 'Pengaruh Pendapatan Pegadaian, Jumlah Nasabah, Dan Tingkat Inflasi Terhadap Penyaluran Kredit Pada Perum Pegadaian Syariah Cabang Dewi Sartika Periode 20042008', Jurnal Universitas Gunadarma.

Rahmawati, M. (2016) 'Pengaruh Jumlah Nasabah,Harga Emas Dan Tingkat Inflasi Terhadap Penyaluran Kredit Gadai', Universitas Muhammadiyah Ponogoro. 
Rivandi, M. (2017) 'Faktor Fundamental Sebagai Penentu Initial Return', Jurnal Benefita, Vol. 2(No. 3), pp. 299-307. doi: DOI : 10.22216/jbe.v2i3.2346.

Rivandi, M., Saleh, S. M. and Septiano, R. (2017) 'Leverage, Profitabilitas, Ukuran Perusahaan, Pengungkapan Corporate Social Responsibility dengan Pendekatan Kausalitas', Jurnal Pundi, Vol. 01(No. 01), pp. 11-22.

Rosa, Y. Del, Husni, E. and Idwar (2017) 'Pengaruh Tingkat Inflasi Dan Pendapatan Pegadaian Terhadap Penyaluran Kredit Rahn Pada Pegadaian Syariah Di Indoneia Tahun 2007- 2015', Menara Ekonomi, III(5), pp. 116-127.

Sari, N. M. J. and Abudanti, N. (2016) 'Pengaruh DPK,ROA,Iflasi Dan Suku Bunga SBI Terhadap Penyaluran Kredit Pada Bank Umum', E-Jurnal Manajemen Unud, 5(11), pp. 7156 7184.

Sugiyono (2011) Metode penelitian Kuantitaif,Kualitatif dan R\&D. Bandung: Alfabeta.

Sugiyono (2015) Statistika untuk Penelitian. Bandung: Alfabeta.

Widiarti, T. and Sinarti (2013) 'Pengaruh Pendapatan, Jumlah Nasabah, Dan Tingkat Inflasi

Terhadap Penyaluran Kredit Pada Perum Pegadaian Cabang Batam Periode 2008-2012', pp. 1-6. 